Grant-in-Aid for Scientific Research (S)

Real Estate Markets, Financial Crisis, and Economic Growth

: An Integrated Economic Approach

Working Paper Series No.69

\author{
Housing Wealth Effects in Japan: \\ Evidence Based on Household Micro Data
}

Masahiro Hori
and

Takeshi Niizeki

September, 2017

HIT-REFINED PROJ ECT

Institute of Economic Research, Hitotsubashi University

Naka 2-1, Kunitachi-city, Tokyo 186-8603, J APAN

Tel: $+81-42-580-9145$

E-mail: hit-refined-sec @ier.hit-u.ac .jp

http://www.ier.hit-u.ac.jp/hit-refined/ 


\title{
Housing Wealth Effects in Japan: Evidence Based on Household Micro Data ${ }^{\dagger}$
}

\author{
Masahiro Hori $^{a}$ and Takeshi Niizeki ${ }^{a, b \ddagger}$ \\ ${ }^{a}$ Economic and Social Research Institute, Cabinet Office \\ ${ }^{b}$ Ehime University
}

\begin{abstract}
Using micro data covering almost 500,000 Japanese households over the period 1983-2012, this paper examines to what extent household consumption responds to changes in housing wealth. Instead of employing self-reported or regionally averaged values of housing wealth, we directly estimate the housing wealth of individual households by matching several official statistics, providing an ideal setting to identify housing wealth effects on consumption. Employing cross-section and pseudo-panel based regressions, we find that the marginal propensity to consume (MPC) out of housing wealth is approximately 0.0008-0.0013 for nondurable consumption and 0.0059-0.0082 for total consumption. We further find that the consumption response of older households is larger than that of younger households, which is consistent with the pure wealth effects hypothesis.
\end{abstract}

Keywords: Housing wealth, household consumption, life cycle/permanent income hypothesis JEL Classification: D12, D31, E21

\footnotetext{
${ }^{\dagger}$ This paper forms part of our microdata-based research on household consumption and macroeconomic policies in Japan. We are grateful to Takashi Unayama for his helpful comments as the discussant of our paper at the 2016 spring meeting of the Japanese Economic Association, and to Michio Naoi for his helpful discussion. We would also like to thank Keiko Murata, Koichiro Iwamoto, Junya Hamaaki, Fumihiko Suga, Daisuke Moriwaki, and other ESRI colleagues for their comments and support. Special thanks go to the Statistics Bureau of Japan for providing us with the microdata from the Family Income and Expenditure Survey (FIES) and to Ralph Paprzycki for his excellent English editing service. This study was also supported by JSPS KAKEN(S) \#25220502. The views expressed in this paper are those of the authors and do not represent those of the institutions with which we are affiliated.

₹ Corresponding author. Faculty of Law and Letters, Ehime University, 3 Bunkyo-cho, Matsuyama City, Ehime 790-8577, Japan. E-mail: niizeki.takeshi.kn@ehime-u.ac.jp (T. Niizeki).
} 


\section{Introduction}

A substantial number of studies have highlighted the existence of a positive correlation between housing price growth and household consumption in developed economies observed in aggregate data. ${ }^{1}$ Looking at the case of Japan, Figure 1 shows the growth rate of the price of (residential) land per square meter and household final consumption expenditure (excluding the imputed service of owner-occupied dwellings) over the period 1984-2012. For Japan, changes in land prices per square meter can be considered as a counterpart to housing prices in previous studies, since in Japan approximately $85 \%$ of the value of residential properties derives from the value of the land on which a property sits (while the rest derives from the value of the property itself), as shown later in Table 1. The correlation coefficient between the two series is about 0.54 , which is comparable to the correlation coefficients reported for other developed countries (see footnote 1).

However, the correlation observed in aggregate data may simply reflect macroeconomic factors such as business cycles. A number of studies consequently have utilized microdata to investigate whether a positive correlation between the two series can still be observed after controlling for aggregate factors and household demographic variables. Although these studies have produced conflicting results, a majority of them found a statistically significant positive relationship. $^{2}$

Yet, the existence of a positive correlation even after controlling for aggregate and household demographic effects does not mean that causality necessarily runs from housing prices to household consumption. That is, it is possible that the observed positive correlation largely reflects a third factor such as changes in income growth expectations. If households revise up their future income expectations, their current (non-housing) consumption and housing demand may increase simultaneously, provided that housing supply is irresponsive to changes in expectations in the short run. In this case, there is no causality from housing prices to household consumption.

If causality is found, there are two possible theoretical explanations for this phenomenon. The first (pure wealth effect) explanation is based on the standard life cycle/permanent income hypothesis (LC/PIH), which assumes that households' consumption follows developments in their lifetime wealth. Therefore, if unanticipated housing price changes lead to changes in the lifetime wealth of individual households, housing prices and consumption are expected to move simultaneously in the same direction. The second (collateral effect) explanation focuses more on the role of housing wealth as collateral, which households can use to borrow funds to raise

\footnotetext{
${ }^{1}$ For instance, Cooper (2013) finds a correlation coefficient between the two series for the United States of about 0.4 over the period 1970-2012 and of 0.7 during the 2000s. Similarly, using series for the United Kingdom, Attanasio et al. (2009) obtain a correlation coefficient of 0.69 over the period 1970-2006.

2 See, for example, Cooper (2013) and Christelis et al. (2015) on the United States, Campbell and Cocco (2007) and Attanasio et al. (2009) on the United Kingdom, Windsor et al. (2015) on Australia, and Atalay et al. (2014) on Canada and Australia.
} 
consumption to the optimal level. That is, borrowing-constrained homeowners can borrow more to increase consumption when housing prices go up, giving rise to the positive housing price-consumption correlation.

Against this background, the present study, using high-quality data on household-level income, expenditure, and asset holdings covering almost 500,000 households taken from the Japanese Family Income and Expenditure Survey (FIES) over the period 1983-2012, examines (i) to what extent Japanese household consumption responds to changes in housing wealth, and (ii) what the most likely reason for the co-movement of the two series is. To do so, we first conduct a cross-section analysis ${ }^{3}$ following Attanasio and Weber (1994) and Attanasio et al. (2009). Then, as a robustness check, we create a pseudo panel from the FIES and reexamine housing wealth effects in the pseudo panel following Campbell and Cocco (2007).

The novelty of the current study compared to previous studies is that we are able to exploit an extremely rich dataset. First, the large sample size with almost 500,000 households enables us to identify housing wealth effects with unparalleled precision. It also makes it possible to construct a sufficiently reliable quasi-panel of synthetic cohorts. Second, the long coverage of our dataset (1983-2012), which contains Japan's economic bubble period (from the late 1980s to the early 1990s) with dramatic asset price developments, enables us to examine the extent to which volatile movements in land prices cause changes in household consumption.

Third, unlike previous studies employing self-reported or regionally averaged housing prices, we estimate the housing wealth of each household by matching the FIES sample with other official statistics, as discussed in detail in Section 2.2. The heterogeneity in housing wealth among households thus obtained is likely to mitigate possible endogeneity issues arising from measurement errors in housing wealth. ${ }^{4}$ Fourth, in our dataset, it is possible to decompose changes in housing wealth into (a) changes in land prices per square meter and (b) changes in land area measured in square meters. This decomposition is essential to avoid endogeneity since the former can be treated as exogenous whereas the latter is, in general, endogenous for most households.

Last but not least, the rich information contained in the FIES, which collects data on income and expenditures by detailed category for individual households on a diary basis (and not through retrospective questionnaires), allows us to examine housing wealth effects in Japan in a reliable manner. In our empirical analysis, we use both total consumption (excluding housing-related expenditures) and nondurable consumption as dependent variable. While a number of studies focus on the former, i.e., total consumption, the latter is often preferable, especially when examining the

\footnotetext{
3 To be precise, while the household data from the FIES has a panel structure, since each household's expenditures are surveyed for six months, asset holdings are surveyed only once for each household during this period, so that we treat the data as a cross-section by summing up each household's expenditure over the six-month period that they are surveyed.

${ }^{4}$ On the bias in owner estimates of house values, see Bhatia and Mitchell (2016) and the studies mentioned therein.
} 
validity of the LC/PIH. ${ }^{5}$ Moreover, some previous studies even fail to exclude housing-related expenditure from their total consumption due to the lack of data. This is potentially problematic, since housing rent (which represents a major part of housing-related expenditure) is likely to increase when land prices rise, causing an upward bias in housing wealth effect estimates.

The remainder of the study is organized as follows. The next section provides a review of the related literature and introduces our FIES-based micro dataset, while Section 3 describes our empirical strategy and estimation methodology. Section 4 then presents the results (of both the cross-section and pseudo-panel based regressions) and discusses their implications. Finally, Section 5 concludes.

\section{Related literature and data construction}

\subsection{Literature review}

Following the strategy proposed by Attanasio and Weber (1994), which is summarized in Atalay et al. (2014), we compare the marginal propensity to consume (MPC) out of housing wealth between old and young households to find the most plausible explanation for the co-movement of land prices and household consumption. If the estimated MPC is larger for older than for younger households, household behavior is consistent with the pure wealth effects hypothesis, since the standard LC/PIH predicts that those with a shorter remaining life-span should consume a larger part of windfall gains such as an increase in housing wealth than those with a longer remaining life-span, i.e., the young, provided that bequest motives do not play a role. On the other hand, if the consumption of younger households is more responsive to changes in housing wealth than that of older households, this behavior would be consistent with either the collateral or the common factor hypothesis. In this case, we further investigate whether household consumption responds to anticipated increases in housing wealth. If household consumption is responsive to anticipated rises in housing wealth, we conclude that the collateral hypothesis is the most plausible explanation. If not, the third factor hypothesis is chosen as a major explanatory factor for the co-movement of land prices and household consumption in Japan.

Empirical studies examining the different possible explanations arrive at different conclusions depending on the country they focus on and the type of data used. Using a pseudo-panel of households in the U.K., Campbell and Cocco (2007) show that the nondurable consumption response to changes in housing prices is highest for old homeowners and lowest for young renters, providing support for the pure wealth effect hypothesis. On the other hand, panel data-based studies on the U.S. (Cooper, 2013) and Australia (Windsor et al., 2015) as well as a cross-sectional study

\footnotetext{
5 The LC/PIH assumes that households smooth out the service flow from (the consumption of) items they purchased, not the expenditures themselves. Therefore, as highlighted by Hayashi (1985), it is preferable to exclude items with some durability, i.e., durable goods, semi-durable goods, and services, from expenditures. Based on these considerations, in the current analysis nondurable consumption is defined as total consumption expenditures minus durable, semi-durable, and service expenditures.
} 
on Australia and Canada (Atalay et al., 2014) appear to support the collateral effect hypothesis. Finally, the common factor effect hypothesis is supported by cross-sectional studies on the U.K. (Attanasio and Weber, 1994, and Attanasio et al., 2009), as well as by a panel-based study on Australia (Windsor et al., 2015).

Another issue this study focuses on is the magnitude of the housing wealth effect, i.e., the MPC. Previous studies on the estimated magnitude can be broadly categorized into the following three groups. ${ }^{6}$ The first group consists of studies that do not obtain a statistically significant relationship between housing prices and consumption. For instance, Skinner (1989), using the Panel Study of Income Dynamics (PSID) in the United States, finds no statistically significant coefficient once fixed effects are controlled for. More recently, Browning et al. (2013), employing Danish household-level panel data, distinguish anticipated price changes from unanticipated ones by estimating the housing price stochastic process and show that household consumption is irresponsive even to unanticipated price changes, which contradicts the prediction derived from the standard LC/PIH. The second group consists of studies reporting modest MPCs out of housing wealth, somewhere between 0 and 0.03 . The estimated MPCs are as follows: 0.0077-0.0095 (Christelis et al., 2015) for the United States in the wake of the Great Recession, 0.005-0.009 (Disney et al., 2010) for the U.K., 0.006-0.023 (Atalay et al., 2014) for Canada, 0.002-0.017 (Atalay et al., 2014) for Australia, 0.011-0.024 (Paiella, 2007) and 0.011-0.034 (Paiella and Pistaferri, 2016) for Italy, and 0.02 (Gan, 2010) for Hong Kong.

The third group reports a relatively large MPC out of housing wealth. For the United States, Mian et al. (2013), using county-level panel data from 2006 to 2009, show that the MPC is $0.054{ }^{7}$ whereas Copper (2013) and Pistaferri (2016), employing the PSID, find that the MPC is somewhere in the region of 0.037-0.070. For Canada, Bhatia and Mitchell (2016) employ the hedonic approach to estimate housing prices and conclude that the MPC is 0.039-0.054.

Turning to Japan, there are only a limited number of studies on the housing wealth effect based on micro data (including prefectural data) and, as for other developed economies, a consensus has yet to be reached. Using prefectural panel data, Dekle (1994) and Ogawa et al. (1996) arrive at opposite findings. While the former finds statistically significant housing wealth effects, the latter show that the positive co-movement disappears once financial wealth is controlled for. Using household-level panel data from the Japanese Panel Survey of Consumers (JPSC), Hori and Shimizutani (2004) also do not detect statistically significant housing wealth effects among Japanese households. More recently, Naoi (2014a, b), employing household-level panel data from

\footnotetext{
${ }^{6}$ Note that in this section we only review micro data-based studies. For the results of analyses based on aggregate datasets, see, for example, Case et al. (2005, 2011), Slacalek (2009), Ludwig and Slok (2004), Dvornak and Kohler (2007), and Phang (2004).

7 The value of 0.054 for the MPC is for total consumption. The MPC for the consumption of automobiles is 0.023 , that of non-durables 0.016 , that of other durables 0.011 , and that of groceries 0.004 .
} 
the Keio Household Panel Survey (KHPS), has shown that the elasticity of total consumption with respect to self-reported housing wealth might be about $0.01 \%$ in Japan, although whether the estimated coefficients are significant depends on the model specification.

\subsection{Data description}

\subsubsection{Family Income and Expenditure Survey (FIES)}

This study uses microdata from the FIES collected between 1983 and 2012. The FIES is conducted monthly by the Ministry of Internal Affairs and Communications and is an important source of information for the construction of aggregate data such as the Consumer Price Index.

The FIES provides detailed information on household characteristics, income, expenditures, and financial asset holdings for a nationally representative sample of about 8,000 households each month. Each household is surveyed for a period of six consecutive months, and one-sixth of the sample households are replaced by new households every month. ${ }^{8}$ As data on financial assets are not available for single-person households, we use multiple-person households only in the empirical analyses below. We also dropped households whose housing tenure status changed during the six-month period as well as households whose head is less than 20 years old, since their consumption patterns are likely to contain a considerable amount of noise. The resulting total number of households is 497,661 (consisting of roughly 360,000 homeowning and 140,000 renting households).

The FIES requests survey respondents to keep a diary to report monthly income and expenditures, which is believed to be more accurate than information obtained from retrospective question-based surveys. The FIES also contains information on the previous year's pretax annual household income and a wide variety of household characteristics such as the age of the household head, the number of household members, etc. Information on financial assets and liabilities is also collected once during the six-month survey period, for a limited number of households before 2002 (approximately 18.2\% of 316,390 households) and for almost all sample households from 2002 onward. As for housing wealth, while the FIES unfortunately does not contain information on housing wealth itself, we can obtain information on the approximate residential address, the housing tenure status (homeowner or renter) for all households, and the floor space, land area, structure of the dwelling, and year of construction of the dwelling for homeowner households. Therefore, the next subsection briefly describes how we estimated the value of housing wealth for individual households from that information.

\subsubsection{Estimation of housing wealth}

\footnotetext{
8 Taking the January 2000 survey as an example, the first one-sixth of sample households are surveyed from August 1999 to January 2000, the second one-sixth are surveyed from September to February 2000, ..., and the sixth one-sixth are surveyed from January 2000 to June 2000.
} 
Housing wealth consists of two parts: a house (building) and the land on which it sits. Since approximately $85 \%$ of housing wealth in Japan derives from the value of land (see Table 1), we describe the estimation methodology for the latter (land assets) first and then turn to the estimation of the former (house assets).

Although households may hold multiple houses, the FIES does not provide any information about additional houses. Thus, we restrict the estimation of household real assets in this study to the value of households' current home. ${ }^{9}$ To estimate the value of residential land assets owned by individual households, we determine the approximate address where sample households lived (to the greatest level of precision possible using multiple official statistics ${ }^{10}$ ) and use the price of residential land at the closest survey location ${ }^{11}$ in the "Land Market Value Publication (Chika-koji)" provided by the Ministry of Land, Infrastructure, Transport and Tourism (MLIT) ${ }^{12}$ as the relevant land price. Finally, we estimate the nominal value of survey households' residential land assets by multiplying the land price per square meter at the location closest to households' approximate address determined in the manner just described and the land area (square meters) of their home reported in the FIES.

Turning to the estimation of the value of survey households' house, the FIES provides information on the floor space (in square meters), the structure of the dwelling (wooden, reinforced concrete, etc.), and the year of construction. Following the method employed by Takayama et al. (1989), we match the FIES data with data on average construction costs (by type of building structure, municipality, and construction year) reported in the "Annual Report of Building Construction" (1953-2012) to calculate the value of house assets. The house value is basically constructed by multiplying the construction cost per square meter by the total floor space homeowners report. Then, the house value evaluated in this manner is depreciated up to the survey year using certain depreciation rates that depend on the structure of the dwelling. ${ }^{13}$

Table 1 presents the basic statistics of major variables in the dataset we constructed in the manner described above. The mean of housing wealth for homeowners is about 32.6 million yen, and $85.7 \%$ of it derives from the value of land, as highlighted in Section 1 . The annual average of capital gains from land for homeowners, calculated as the current year's land value minus the previous year's land value, is negligible. However, if the sample period is split into the bubble

\footnotetext{
${ }^{9}$ According to the 2009 National Survey of Family Income and Expenditure (NSFIE), the estimated mean of the value of households' home and the land on which it sits (for two or more person households) is approximately 20 million yen, whereas the estimated mean of the value of non-owner occupied homes (buildings and land) owned by households is about 5 million yen.

10 See Iwamoto et al. (2015) for details.

11 The median (mean) distance for our sample homeowner households is 0.53 (1.09) kilometers.

12 The "Land Market Value Publication" annually reports land prices per square meter (of 5,000-20,000 residential sites) all over Japan as of January 1.

13 Following the "Ministerial Ordinance for Durable Years of Depreciable Assets," we employ the following annual depreciation rates: $9.9 \%$ for wooden structures, $4.8 \%$ for reinforced concrete or steel-frame structures, and $5.9 \%$ for other structures.
} 
period (1983-1991) and the post-bubble period (1992-2012), the annualized average capital gains (losses) are 2.48 million yen and -1.01 million yen, respectively. These relatively large capital gains (losses) mean that it is possible that housing wealth effects can be observed.

\section{Methodology}

To examine housing wealth effects, we employ the theoretical prediction of the standard LC/PIH that current consumption depends on current asset holdings and human wealth (i.e., the discounted sum of expected future income). Since human wealth is unobservable, it is proxied by household income, ${ }^{14}$ the industry in which the household head works, and the type of work ${ }^{15}$ of the household head. Thus, the consumption function takes the following form:

$$
C_{i}=\beta_{0}+\beta_{1} H W_{i}+\beta_{2} F W_{i}+\beta_{3}{ }^{\prime} Z_{i}+\varepsilon_{i},
$$

where $C_{i}$ is the annualized ${ }^{16}$ household consumption, $H W_{i}$ is the housing wealth, and $F W_{i}$ is the net financial wealth (financial wealth minus outstanding debt) of household $i$.

$Z_{i}$ is a vector of control variables that include the previous year's (pre-tax) household income, ${ }^{17}$ the industry in which the household head works, and the type of work of the household head in order to control for heterogeneous human wealth; the age of the household head, family size, the number of household members aged 65 and over, and the number of household members aged 15 and under to control for household needs at different life stages; and the sex of the household head and the prefecture of residence to control for other factors affecting household consumption. Dummies for the first month in which a household was surveyed as well as year dummies are also included to adjust for seasonality and eliminate the effects of common macroeconomic factors. In addition, following Attanasio and Weber (1994) and Attanasio et al. (2009), cohort dummies are created based on 19 ranges for the year of birth $(-1919,1920-1922, \ldots$, 1968-1970, and 1971-) and added as independent variables to control for cohort effects. All monetary variables are converted into real terms using prefectural consumer price indexes (CPIs). Prefectural CPIs instead of the nationwide CPI are employed to eliminate regional differences in price levels as much as possible. ${ }^{18}$ For the same reason, an urban dummy, which takes unity if the household lives either in the capital, Tokyo, or one of the government-designated cities, ${ }^{19}$ is also

\footnotetext{
14 If it is assumed that household income follows a first-order autoregressive process, human wealth can be described as a function of current household income.

${ }^{15}$ Types of work are classified into 12 categories (sole proprietors, public employees, unemployed, etc.).

16 Annualized household consumption is obtained by simply multiplying monthly average consumption by 12 .

17 Ideally, we would use current disposable income. However, because current disposable income is not available for self-employed households, we use the previous year's (pre-tax) household income, which is available for all households, instead.

${ }^{18}$ If we were to use the nationwide CPI, we might obtain a positive estimate for $\beta_{1}$ simply because households that live in urban areas, where land prices are higher, face higher prices. To a large extent, this possibility is probably eliminated by the inclusion of prefecture dummies in the regression. However, differences in prefectural price levels may not be constant over time. To address this issue to the greatest possible extent, the prefectural CPIs are employed in the current analysis.

${ }_{19}$ Japan consists of 47 prefectures and each prefecture has a capital city, which generally is the most populous city
} 
included in the regression to control for the difference in price levels between urban and rural areas. Equation (1) is estimated using ordinary least squares (OLS).

Before presenting the benchmark results, we should draw attention to potential endogeneity issues with regard to Equation (1). We believe that the error term may contain at least three possible omitted variables. The first of these is whether households just purchased a new house. Households that recently purchased a new house may be likely to also buy durable goods such as a refrigerator and/or washing machine as well as nondurable goods such as curtains. In this case, the impact of new housing purchases would be picked up by the error term, resulting in omitted variable bias. Fortunately, the FIES contains information on the year of construction of homeowners' dwelling. We therefore dropped from our sample homeowners that live in a house that is no more than one year old in order to eliminate to the greatest extent possible the potential endogeneity problem caused by recent housing purchases. ${ }^{20}$

The second possible source of omitted variable bias is that other factors apart from those included in our estimation may affect permanent income. As mentioned, we include household income, the industry in which the household head works, and the type of work of the household head in the regression as proxies for households' permanent income. Although the industry of occupation dummies enable us to control for differences in average permanent incomes between, say, the mining industry on the one hand and finance and insurance on the other, it does not allow us to consider differences in permanent income among workers within such broad industry classifications, such as between workers at major city banks and small regional banks. ${ }^{21}$ In this study, we try to overcome this potential omitted variable bias in two ways. The first is based on the fact that, in the framework of the standard LC/PIH, lifetime resources consist of (i) housing wealth, (ii) net financial wealth, and (iii) human wealth, and that the share of human wealth becomes negligible after retirement. Since the former two variables are already included as explanatory variables in our analysis, this means that we can essentially control for households' entire permanent income if we confine our sample to retired households. The estimation result of this additional exercise will be reported in Table 2 below. The second way in which we try to alleviate possible omitted variable bias is to utilize the (pseudo) panel, the construction of which is described in Section 4.2 below and which enables us to take the first difference of logged variables.

of that prefecture. Government-designated cities are cities with a population of 500,000 inhabitants or more that have been granted special rights by the government. Thus, most government-designated cities are prefectural capitals, but some are not.

${ }^{20}$ This fails to address the issue if households purchased a used house. We attempt to resolve this issue using the pseudo-panel dataset in Subsection 4.2.

${ }^{21}$ Similarly, in Japan's dual labor market, the size of the firm that the household head works for may be another determinant of the household's permanent income. However, although the FIES contains information on the size category (in terms of the number of employees) of the firm that the household head works for, we decided not to use this variable in our regression, since it is available only for about $60 \%$ of households in the sample. We ran regressions using this smaller sample to include the size of the firm (number of employees) that the household head worked for as a robustness check and found that the estimates for housing wealth were quite similar to the results shown in Table 2. 
According to the standard consumption Euler equation, the growth rate of consumption depends on the subjective discount factor and real interest rates, but not permanent income. Thus, employing pseudo-panel data may be another possible solution to address the omitted variable bias.

The third possible omitted variable in Equation (1) is household preferences. For instance, more frugal households tend to forgo consumption today in order to accumulate wealth. Thus, unobserved household frugality potentially causes the OLS estimator for $\beta_{1}$ to be downward-biased. Employing the pseudo-panel data already mentioned will eliminate the impact of household preferences and other time-invariant unobserved factors.

Overall, while we think that most of the possible omitted variable bias due to the first two sources is controlled for by employing the methodologies mentioned above, we recognize that the last source, household preferences, may still be present in the error term in Equation (1) unless the pseudo-panel data are employed. Nevertheless, employing the cross-sectional analysis provides a useful starting point, for the following two reasons. First, while the pseudo-panel data allow us to eliminate the effects of time-invariant unobserved factors, constructing the panel from the cross-sectional data we end up with a much smaller sample (consisting of about 1,000 observations compared to 200,000-500,000 observations in the cross-sectional data) and hence much smaller household heterogeneity. Second, as discussed in detail in Section 4.2, Attanasio et al. (2009) and Campbell and Cocco (2007) reach different conclusions regarding the most plausible explanation for the positive correlation between housing prices and household consumption based on the same British cross-sectional micro data, the Family Expenditure Survey (FES). Specifically, while Attanasio et al. (2009) use the data for cross-sectional analyses and show that, among the different age groups, the MPC is largest for the young, leading them to conclude that the common factor hypothesis is the most plausible, Campbell and Cocco (2007) construct a pseudo-panel from the same dataset and show that the MPC is largest for older homeowners, which is consistent with the pure wealth effect hypothesis. It is worth investigating whether the same conflicting results depending on the type of analysis employed are also observed when using Japanese household microdata.

\section{Results}

\subsection{Cross-sectional analysis}

The estimate of $\beta_{1}$ can be interpreted as the MPC out of housing wealth, since both consumption and housing wealth in Equation (1) are in levels. Table 2 reports the estimation results using nondurable and total consumption (excluding housing-related expenditure) as the dependent variable. In specifications (1) and (5), which make full use of the large sample size, the MPC out of housing wealth is 0.0010 for nondurable and 0.0033 for total consumption. Specifications (2) and (6) show that controlling for net financial wealth leaves the estimated MPCs essentially unchanged. 
The results for specifications (3) and (7), which, as in Campbell and Cocco (2007), include a dummy for young households where the head of household is aged 40 or under, indicate that the MPC of younger households is smaller than that of older households and that the difference is statistically significant at the $1 \%$ level, which is consistent with the pure wealth effect hypothesis. ${ }^{22}$ Finally, in specifications (4) and (8), the sample is confined to households whose head is aged 65 or older to eliminate the potential bias arising from imperfectly capturing the human wealth component of permanent income. The MPCs are 0.00143 for nondurable and 0.00329 for total consumption - values that are not very different from the estimates in specifications (2) and (6). We can therefore conclude that our estimates of $\beta_{1}$ do not suffer from any serious omitted variable bias.

While international comparisons of MPCs are anything but straightforward due to differences in the definition of consumption (nondurable, total, etc.), measures of housing wealth (self-reported, national/regional prices, hedonically estimated prices), sample coverage (nationally representative, only homeowners, etc.), estimation methodology (OLS, instrumental variable, etc.), and data structure (cross-section and panel), it nevertheless appears that our estimated MPCs are close to the lower end of estimates reported for developed countries. However, it is possible that the low MPC estimates may simply be the result of downward bias due to the omission of time-invariant household preferences. In the next subsection, we attempt to resolve this issue by creating a pseudo-panel dataset.

\subsection{Pseudo-panel analysis}

This subsection presents the construction of the pseudo-panel dataset. The reasons for constructing such a dataset are as follows. First, such a dataset enables us to control for all time-invariant factors affecting consumption. Second, as highlighted in Section 3, studies for the U.K. arrive at exact opposite conclusions depending on whether cross-sectional (Attanasio et al. 2009) or pseudo-panel analysis (Campbell and Cocco 2007) is employed. By carefully examining and ruling out other possible factors that could be responsible for the conflicting results of the two studies, such as different observation periods or definitions of consumption, Cristini and Sevilla (2014) show that the cause of the conflicting results is the different estimation specifications used. Specifically, while Campbell and Cocco (2007) estimate the log-linearized consumption Euler equation, Attanasio et al. (2009) employ the reduced-form life cycle model.

\footnotetext{
${ }^{22}$ One might argue that once net financial wealth - one of the most important factors determining individuals' or households' borrowing constraints - is controlled for in the regression, the age of the household head should no longer have any impact on whether the household is borrowing-constrained. However, the young may still have a higher probability of being borrowing-constrained since (i) they have a less well established credit history and (ii) given that earnings profiles are typically upward sloping, their consumption level tends to be higher than the currently available resources. In fact, Jappelli (1990), using the U.S. Survey of Consumer Finance, shows that a one year increase in age is associated with a 0.5 percentage point lower probability of being borrowing-constrained, holding other factors including asset holdings constant.
} 
Against this background, following Campbell and Cocco (2007), we create a pseudo-panel from the cross-sectional FIES data and examine whether the results obtained in Section 4.1 are affected by controlling for unobserved time-invariant individual effects and how the consumption function is specified. We create 38 cohorts based on 19 ranges for the year of birth $(-1919$, 1920-1922,..., 1968-1970, and 1971-) and the urban dummy for households living either in Tokyo or one of the government-designated cities. Thus, in contrast with Section 4.1, where simple cohort dummies were used, in this section we also distinguish cohorts in terms of whether they live in urban or rural areas. The reason is that housing wealth volatility historically is larger in urban than in rural areas, which is likely to result in greater variation in the key explanatory variable $\left(\Delta \ln H W_{i, t+1}\right)$. The estimation equation is based on the following consumption Euler equation:

$$
\Delta \ln C_{i, t+1}=\beta_{0}+\beta_{1} r_{t+1}+\beta_{2} \Delta \ln H W_{i, t+1}+\beta_{3} \Delta \ln Z_{i, t+1}+\varepsilon_{i, t+1},
$$

where subscript $i$ denotes the cohort $(i=1,2, \ldots, 38), r_{t+1}$ is the interest rate from period $t$ to period $t+1$, and $\Delta \ln C_{i, t+1}, \Delta \ln H W_{i, t+1}$, and $\Delta \ln Z_{i, t+1}$ are the rates of change in consumption, housing wealth, and cohort characteristics, respectively. ${ }^{23}$ As in Section 4.1, all monetary variables are in real terms. ${ }^{24}$ Note that net financial wealth is dropped from the right-hand side of Equation (2) to ensure that the number of households in each cohort cell is at least $100 .^{25}$

As for any remaining possible omitted variable biases, since we take first differences in Equation (2), all time-invariant factors that might affect the dependent variable, such as household preferences, are controlled for. In addition, in the standard consumption Euler equation, the growth rate of consumption is not dependent on permanent income, which was a potential source of endogeneity in the cross-section analysis. However, there is still at least one variable the omission of which in Equation (2) gives rise to concern, namely, endogenous changes in the quantity of housing (or land area in our case). That is, as highlighted by Paiella and Pistaferri (2016), changes in wealth can be decomposed into (a) changes in asset prices for a given quantity of assets, and (b) changes in the quantity of assets at a given price. While the former can be considered as exogenous to households, the latter, in most cases, is not exogenous. As discussed in Section 3, although we already dropped households from our sample that purchased a house that is no more than a year old, households that purchased a used house that is more than one year old are still left in our sample.

\footnotetext{
${ }^{23}$ Specifically, $\Delta \ln Z_{i, t+1}$ contains the rates of change of the previous year's pretax household income, family size, the number of working household members, the number of household members aged 15 or under, and the number of household members aged 65 or above. In addition, dummies for two-year intervals - for example, an 83-84 dummy that takes a value of one if the year is 1983 or 1984 - are included to eliminate aggregate factors. The reason for using these dummies is that regular year dummies cannot be included, since they are perfectly correlated with the real interest rate.

${ }^{24}$ The real interest rate is calculated by subtracting the ex-post CPI inflation rate from the nominal interest rate provided by the Bank of Japan.

${ }^{25}$ As shown in Section 2, 81.8\% of all households surveyed from 1983 to 2001 did not provide information on their financial wealth. Thus, limiting the sample to households for which information on financial wealth is available leads to a very small sample size.
} 
This could be problematic since such households may also have engaged in purchases of durable goods such as a refrigerator or washing machine or of nondurable goods such as curtains when they moved in. It is crucial to hold the quantity component of assets (in our case, the land area measured in square meters) constant to obtain a consistent estimator for housing wealth effects. In what follows, we take advantage of our data structure, which allows us to decompose the growth rate of housing wealth ( $\Delta \ln H W_{i, t+1}$ ) into two parts: the change in land prices per square meter $\left(\Delta \ln P_{i, t+1}\right)^{26}$ and the land area measured in square meters $\left(\Delta \ln Q_{i, t+1}\right){ }^{27}$ This data structure enables us to eliminate the spurious housing wealth effects driven by endogenous changes in land area. Note that many previous studies relying on self-reported and regional average values of housing wealth fail to distinguish between these two changes, i.e. exogenous price changes for a given quantity and endogenous quantity changes at a given price (the notable exception is Paiella and Pistaferri, 2016). ${ }^{28}$

Against this background, Equation (2) is modified as follows:

$$
\Delta \ln C_{i, t+1}=\beta_{0}+\beta_{1} r_{t+1}+\beta_{2} \Delta \ln P_{i, t+1}+\beta_{3} \Delta Z_{i, t+1}+\varepsilon_{i, t+1},
$$

where the quantity component of housing wealth, the land area in our case (given that housing wealth is the product of the quantity and price of land) is fixed at the average over time for cohort $i$, so that $\Delta \ln Q_{i, t+1}=0$ for all $t$. As a robustness check, we also estimate the following first difference versions of Equation (3):

$$
\begin{gathered}
\Delta C_{i, t+1}=\beta_{0}+\beta_{1} r_{t+1}+\beta_{2}\left(\Delta P_{i, t+1}\right) \bar{Q}_{i}+\beta_{3} \Delta Z_{i, t+1}+\varepsilon_{i, t+1}, \\
\Delta C_{i, t+1}=\beta_{0}+\beta_{1} r_{t+1}+\beta_{2}\left(\Delta P_{i, t+1}\right) Q_{i, t}+\beta_{3} \Delta Z_{i, t+1}+\varepsilon_{i, t+1},
\end{gathered}
$$

where $\bar{Q}_{i}$ is the average land area over time for cohort $i$. In Equation (5), changes in land prices per square meter from time $t$ to $t+1$ are multiplied by the land area at time $t$, which is another possible way to keep the land area constant. ${ }^{29}$

Figure 2 provides a graphic illustration of the relationship between the rate of change in land prices per square meter and the rate of change in nondurable (left panel) and total consumption (right panel). The sample regression lines clearly show a positive relationship between the variables. However, we can only draw definitive conclusions about the relationship after controlling for other factors such as changes in household characteristics and aggregate effects.

\footnotetext{
${ }^{26}$ Each cohort cell consists of at least 100 households and for each household in a cell information on the price of land per square meter at the closest location in the "Land Market Value Publication (Chika-koji)" to their residence is available. Thus, for example, $P_{i, 1984}$ is the average land price for households belonging to cohort $i$ in 1984 and $\Delta \ln P_{i, 1984}$ is the growth rate of the average land price between 1983 and 1984.

27 Note that changes in housing wealth also derive from changes in house (building) value. However, as shown in Table 1, the value of land (and not the house) accounts for approximately 85\% of housing wealth in Japan, so that changes in house values are omitted for simplicity.

${ }^{28}$ Mian et al. (2013) propose another elegant way to tackle the endogeneity problem caused by failing to hold the quantity of assets constant. Focusing on the United States, they instrument changes in housing wealth by the price elasticities of housing supply using county-level microdata.

${ }^{29}$ In the log-log specification, it is also possible to regress $\Delta \ln C_{i, t+1}$ on $\left(\Delta \ln P_{i, t+1}\right) Q_{i, t}$. However, the estimates are not reported in Table 3, since they cannot be interpreted as elasticities of consumption with respect to housing wealth, meaning that we cannot obtain MPCs.
} 
Table 3 displays the estimation results of Equations (2) and (3) using the pseudo-panel we constructed. The estimates can be interpreted as elasticities of consumption with respect to housing wealth, and the implied MPCs are reported at the bottom of Table 3. In specifications (1) through (4), in which the key independent variables are the rate of change of housing wealth ( $\left.\Delta \ln H W_{i, t+1}\right)$, the implied MPCs out of housing wealth using the estimated elasticities are 0.0013 and 0.0049 for nondurable and total consumption, respectively. Given that the estimated MPCs derived from the cross-sectional analysis in Table 2 are 0.0012 and 0.0035, the pseudo-panel estimates are slightly larger, which suggests that the OLS estimator in Equation (1) is downward biased due to the omission of time-invariant household preferences. As for differences in the responses of the young and the old, specifications (2) and (4) show that older households' consumption responds to a greater extent to changes in housing wealth than younger households' consumption and that the MPCs for the young are slightly negative. Given that about $28 \%$ of households in our sample are renters, a possible interpretation of the negative MPC in terms of the LC/PIH is that it reflects forward-looking behavior in that renters increase their saving (and cut back consumption) in order to be able to purchase more expensive houses in the future. In specifications (5) through (8), our main explanatory variable, the rate of change of housing wealth, is replaced by the rate of change of the price of land per square meter to avoid the possible endogeneity arising from endogenous changes in the land area that households own. The implied MPCs are 0.0012 and 0.0082 for nondurable and total consumption, respectively, and the consumption responses are again larger for older households.

Table 4 presents the estimation results based on the first difference specification given in Equations (4) and (5). In this table, the estimates are interpreted as MPCs out of housing wealth. In specifications (1) to (4), where the land area is fixed at the average over time for each cohort, the MPCs are 0.0008 for nondurable and 0.0059 for total consumption, and again the estimates are larger for older households in both cases. In specifications (5) to (8), in which the land area takes the value at time $t$, the estimated MPCs are approximately 0.0010 for nondurable and 0.0068 for total consumption. Although the differences between the MPCs for younger and older households in specifications (6) and (8) are not statistically significant, the point estimates for younger households are smaller than for older households.

In summary, the finding that a larger effect of housing wealth on consumption is observed for older households remains unchanged even in the pseudo-panel analysis, which differs from the conflicting results obtained by Attanasio et al. (2009) and Campbell and Cocco (2007). In addition, the MPCs out of housing wealth in the pseudo-panel analysis are $0.0008-0.0013$ for nondurable consumption and 0.0059-0.0082 for total consumption, values that are almost equal to or slightly larger than the estimates obtained in the cross-sectional analysis and are smaller than the MPCs reported for other developed countries (see Section 2.1). 
Regarding the estimates obtained in this study, it should be noted that the FIES only contains information on households' home. That is, if households own other properties that are rented out, only the value of the house in which they live is included in our estimated value of housing wealth. As already mentioned in footnote 9, according to the 2009 NSFIE, the estimated mean value of owner-occupied homes was approximately 20 million yen, while the estimated value of non-owner occupied homes was about 5 million yen, which is a non-negligible amount. In fact, Gan (2010), using microdata for Hong Kong, found that housing wealth effects are larger for households owning multiple houses than a single house. It should therefore be kept in mind that our estimates are somehow downward-biased.

\subsection{Further evidence: homeowners vs. renters}

In the previous subsections, MPCs out of housing wealth were estimated for all sample households and compared across age groups, following the empirical strategy by Attanasio and Weber (1994). However, a more prudent method to examine housing wealth effects is to estimate MPCs for homeowner and renter households separately. While higher house prices may encourage renter households to save more in order to be able to afford their own home in the future, higher house prices may also have the opposite effect, if renters feel that buying a home is increasingly out of reach, they give up saving for a home, and increase their consumption instead. Therefore, in this subsection, we conduct our cross-sectional and pseudo-panel analyses separately for homeowner households and renter households as a robustness check of our wealth effect estimates.

Table 5 shows the regression results based on the cross-sectional data when the sample is confined to homeowners. In specifications (2) and (6), the MPCs out of housing wealth are 0.0010 (nondurable consumption) and 0.0027 (total consumption), which are significant but slightly smaller than the corresponding estimates in Table 2, which are based on the sample including renters. Further, as before, we find that the estimated MPCs are larger for older than for younger households, which is consistent with the LC/PIH (pure wealth effects hypothesis).

Table 6 summarizes the regression results based on the cross-sectional data when the sample is confined to renters. Since housing wealth for renters is zero, we cannot simply run a regression using housing wealth as an independent variable. To circumvent this issue, we replace it with the average housing wealth in the city where renters reside. According to the estimates using specifications (2) and (6), the MPCs out of housing wealth are 0.0002 (nondurable consumption) and 0.0011 (total consumption). Both values are statistically significant and positive, but very small. This means that renters living in a region where the cost of purchasing a house is higher than in other regions tend to consume slightly more, holding all other factors constant. At first glance, this might appear consistent with an expectations-based explanation, a variant of the third-factor hypothesis. That is, positive news regarding future income simply simultaneously boost both 
spending by renters and land prices. However, this cannot be the case, since the MPCs for young households are smaller (not larger) than for older households, which contradicts the prediction derived from the third-factor hypothesis.

There are at least two ways to interpret the result. The first possibility is that renters faced with higher house prices tend to consume more simply because they have given up on buying their own home one day and increase their non-housing expenditure instead. If this tendency is observed more strongly for older than for younger households, this interpretation could be a possible explanation for the estimation results in Table 6. Another possibility is that the statistically significant positive estimates in Table 6 are spurious and contaminated by omitted variable biases. To examine which interpretation is correct, in specifications (4) and (8) we further confine the sample to those aged 65 or older and find that the MPCs are no longer statistically different from zero. This suggests that the estimates in specifications (2) and (6) are possibly upwardly biased due to the omission of permanent income. Although it would be worthwhile to investigate in more detail which of the possible interpretations is more reasonable, we leave this issue for future research, since renters' response to changes in housing prices is not the main focus of our study.

It is also possible to confine the sample to homeowners and create pseudo-panel data just as in Section 4.2. (On the other hand, the number of renter households is too small to construct a pseudo-panel.) Tables 7 and 8 display the regression results based on the constructed pseudo-panel data for homeowner households. The estimated MPCs are 0.0006-0.0015 (nondurable consumption) and $0.0052-0.0074$ (total consumption). These estimates are statistically significant and similar to those obtained from the sample including renters. Furthermore, as in Tables 3 and 4, the MPCs tend to be larger for older than for younger households.

In sum, since the estimation results remain largely unchanged even when we exclude renters from the sample both in the cross-sectional and pseudo-panel analyses, we conclude that our main finding still holds that the most plausible explanation for the observed comovement between housing wealth and household consumption in Japan appears to be pure wealth effects.

\subsection{Macroeconomic implications}

As shown in Figure 1, Japan experienced a rapid increase in land prices per square meter during the period 1986-1991 and a significant drop during the years 1991-1994. In this subsection, we examine to what extent the volatile movement in land prices per square meter during the asset bubble and its aftermath affected household consumption by utilizing the estimates obtained above. Note that since the microdata used in other studies on Japan, such as data from the JPSC and KHPS, do not cover the period mentioned above, in particular the bubble period, ${ }^{30}$ this, to the best of our knowledge, is the first attempt to investigate the extent to which changes in land prices per square

30 The JPSC and KHPS started in 1993 and 2004, respectively. 
meter contributed to the dynamics of household consumption during the bubble and its collapse based on microdata.

The results of this exercise are summarized in Table 9. From 1986 to 1991, the average nominal land price per square meter rose by $154 \%$. Multiplying this by 0.0688 , which is the estimated elasticity of total consumption with respect to land prices per square meter obtained in specification (7) in Table 3, suggests that the increase in land prices boosted consumption by $10.6 \%$. Combining this with the fact that the actual growth rate of final consumption expenditure of households (excluding the imputed service of owner-occupied dwellings) during this period was $33.8 \%$, this back-of-the-envelope calculation implies that about $31 \%$ of the growth rate of household consumption during the bubble period is explained by the surge in land prices, ${ }^{31}$ which is consistent with the adjusted $R^{2}$ derived from specification (7) in Table 3, 0.29.

The second row in Table 5 shows the result of the same exercise for the period 1991-1994. Our estimate indicates that the drop in land prices reduced household consumption by 2.8\%. Given that actual household consumption continued to grow by $8.9 \%$ between 1991 and 1994, our estimate suggests that during this period the decline in land prices simply lowered the rate of increase in household consumption; that is, household consumption would have increased by $2.8 \%$ more if land prices had remained unchanged.

\section{Conclusion}

This paper examined to what extent household consumption responds to changes in housing wealth using Japanese microdata covering approximately 500,000 households over the period 1983-2012. The cross-sectional analysis revealed that, keeping other factors fixed, households with greater housing wealth spend more, and the estimated MPCs are 0.0012 for nondurable and 0.0035 for total consumption. In addition, the comparison of consumption patterns between younger and older households showed that the estimates for older households were larger than those for younger households, which is consistent with the pure wealth effect hypothesis.

In addition, as a robustness check, we conducted regression analyses using pseudo-panel data constructed from the cross-sectional FIES data. The derived MPCs are $0.0008-0.0013$ for nondurable consumption and 0.0059-0.0082 for total consumption and, again, the consumption of older households was found to be more responsive to changes in housing wealth than that of younger households.

Judging from these regression results, it appears that housing wealth effects can be observed in Japan, but they are weaker than in other developed countries. Moreover, the pure wealth effect

\footnotetext{
31 In a similar vein, Mian et al. (2013), using county-level data for the United States, conclude that almost $40 \%$ of the decline in total consumption relative to trend from 2006 to 2009 was due to the fall in home values.
} 
channel provides the most plausible explanation for the positive relationship between consumption and housing wealth, which is consistent with the findings by Campbell and Cocco (2007). 


\section{References}

[1] Atalay, K., Whelan, S. and Yakes, J., "House Prices, Wealth and Consumption: New Evidence from Australia and Canada," Review of Income and Wealth, 62(1), 69-91, 2014.

[2] Attanasio, O. P., and Weber, G., "The UK Consumption Boom of the Late 1980s: Aggregate Implications of Microeconomic Evidence,” The Economic Journal, 104(427), 1269-1302, 1994.

[3] Attanasio, O. P., Blow, L., Hamilton, R., and Leicester, A., "Booms and Busts: Consumption, House Prices and Expectations,” Economica, 76(301), 20-50, 2009.

[4] Bhatia, K., and Mitchell, C., "Household-specific Housing Capital Gains and Consumption: Evidence from Canadian Microdata," Regional Science and Urban Economics, 56, 19-33, 2016.

[5] Browning, M., Gortz, M., and Leth-Petersen, S., "Housing Wealth and Consumption: A Micro Panel Study,” The Economic Journal, 123(568), 401-428, 2013.

[6] Campbell, J. Y., and Cocco, J. F., "How Do House Prices Affect Consumption? Evidence from Micro Data,” Journal of Monetary Economics, 54, 591-621, 2007.

[7] Case, E. K., Quigley, M. J., and Shiller, J. R., “Comparing Wealth Effects: The Stock Market versus the Housing Market,” Advances in Macroeconomics, 5(1), 1-32, 2005.

[8] Case, E. K., Quigley, M. J., and Shiller, J. R., “Wealth Effects Revisited 1978-2009,” NBER Working Paper Series, No. 16848, 2011.

[9] Christelis, D., Georgarakos, D., and Jappelli, T., "Wealth Shocks, Unemployment Shocks, and Consumption in the Wake of the Great Recession,” Journal of Monetary Economics, 72, 21-41, 2015.

[10] Cooper, D., "House Price Fluctuations: The Role of Housing Wealth as Borrowing Collateral," The Review of Economics and Statistics, 95(4), 1183-1197, 2013.

[11] Cooper, D., and Dynan, K., "Wealth Effects and Macroeconomic Dynamics," Journal of Economic Surveys, 30(1), 34-55, 2016.

[12] Cristini, A., and Sevilla, A., "Do House Prices Affect Consumption? A Re-assessment of the Wealth Hypothesis,” Economica, 81, 601-625, 2014.

[13] Disney, R., Gathergood, J., and Henley, A., "House Price Shocks, Negative Equity, and Household Consumption in the United Kingdom,” Journal of the European Economic Association, 8(6), 1179-1207, 2010.

[14] Dvornak, N., and Kohler, M., "Housing Wealth, Stock Market Wealth and Consumption: A Panel Analysis for Australia,” The Economic Record, 83(261), 117-130, 2007.

[15] Gan, J., "Housing Wealth and Consumption Growth: Evidence from a Large Panel of Households,” The Review of Financial Studies, 23(6), 2229-2267, 2010. 
[16] Hayashi, F., “The Permanent Income Hypothesis and Consumption Durability: Analysis Based on Japanese Panel Data,” The Quarterly Economic Review, 100(4), 1083-1113, 1985.

[17] Hori, M., and Shimizutani, S., “Asset Holding and Consumption: Evidence from Japanese Panel Data in the 1990s,” Seoul Journal of Economics, 17(21), 153-179, 2004.

[18] Iwamoto, K., Niizeki, T., Hamaaki, J., Hori, M., Maeda, S., and Murata, K., "Estimation of Real Assets Holdings by Japanese Households Based on the Microdata from the Family Income and Expenditure Survey” (in Japanese), Economic Analysis (Keizai Bunseki), 189, 63-95, 2015.

[19] Jappelli, T., “Who Is Credit Constrained in the U.S. Economy?” The Quarterly Journal of Economics, 105(1), 219-234, 1990.

[20] Ludwig, A., and Slok, T., "The Relationship between Stock Prices, House Prices and Consumption in OECD Countries,” Topics in Macroeconomics, 4(1), 1-26, 2004.

[21] Mian, A., Rao, K., and Sufi, A., "Household Balance Sheets, Consumption, and the Economic Slump,” The Quarterly Journal of Economics, 128(4), 1687-1726, 2013.

[22] Naoi, M., "Housing Wealth, Reference-Dependent Preferences and Household Consumption" (in Japanese), Keio Journal of Economics, 106(4), 473-487, 2014a.

[23] Naoi, M., "Housing Wealth and Household Consumption Behavior" (in Japanese), in K. Sumita, M. Naoi, and Y. Okumura (eds.) Economic Analysis of Cities, Regions, and Real Estate Markets, 3-26, 2014b.

[24] Ogawa, K., Kitasaka, S., Yamaoka, H., and Iwata, Y., “An Empirical Re-evaluation of Wealth Effect in Japanese Household Behavior,” Japan and the World Economy, 8(4), 423-442, 1996.

[25] Paiella, M., "Does Wealth Affect Consumption? Evidence from Italy," Journal of Macroeconomics, 29, 189-205, 2007.

[26] Paiella, M., "The Stock Market, Housing and Consumer Spending: A Survey of the Evidence on Wealth Effects,” Journal of Economic Survey, 23(5), 947-973, 2009.

[27] Paiella, M., and Pistaferri, L., "Decomposing the Wealth Effect on Consumption," Review of Economics and Statistics, forthcoming.

[28] Pistaferri, L., “Why Has Consumption Remained Moderate after the Great Recession?” mimeo, 2016.

[29] Phang, S., "House Prices and Aggregate Consumption: Do They Move Together? Evidence from Singapore,” Journal of Housing Economics, 13, 101-119, 2004.

[30] Slacalek, J., "What Drives Personal Consumption? The Role of Housing and Financial Wealth,” The B.E. Journal of Macroeconomics (Topics), 9(1), 1-35, 2009.

[31] Skinner, J., "Housing Wealth and Aggregate Saving,” Regional Science and Urban Economics, 19, 305-324, 1989.

[32] Takayama, N., Funaoka, F., Ohtake, F., Sekiguchi, M., and Shibuya, T., "Household Wealth 
and Saving Rates in Japan” (in Japanese), Economic Analysis (Keizai Bunseki), 116, 1-69, 1989.

[33] Windsor, C., Jaaskela, J. P., and Finlay, R., "Housing Wealth Effects: Evidence from an Australian Panel,” Economica, 82(327), 552-577, 2015.

Figure 1

Rate of change in land prices per square meter and final consumption expenditure of households (excluding imputed service of owner-occupied dwellings) Sources: Ministry of Land, Infrastructure, Transport and Tourism; Cabinet Office.

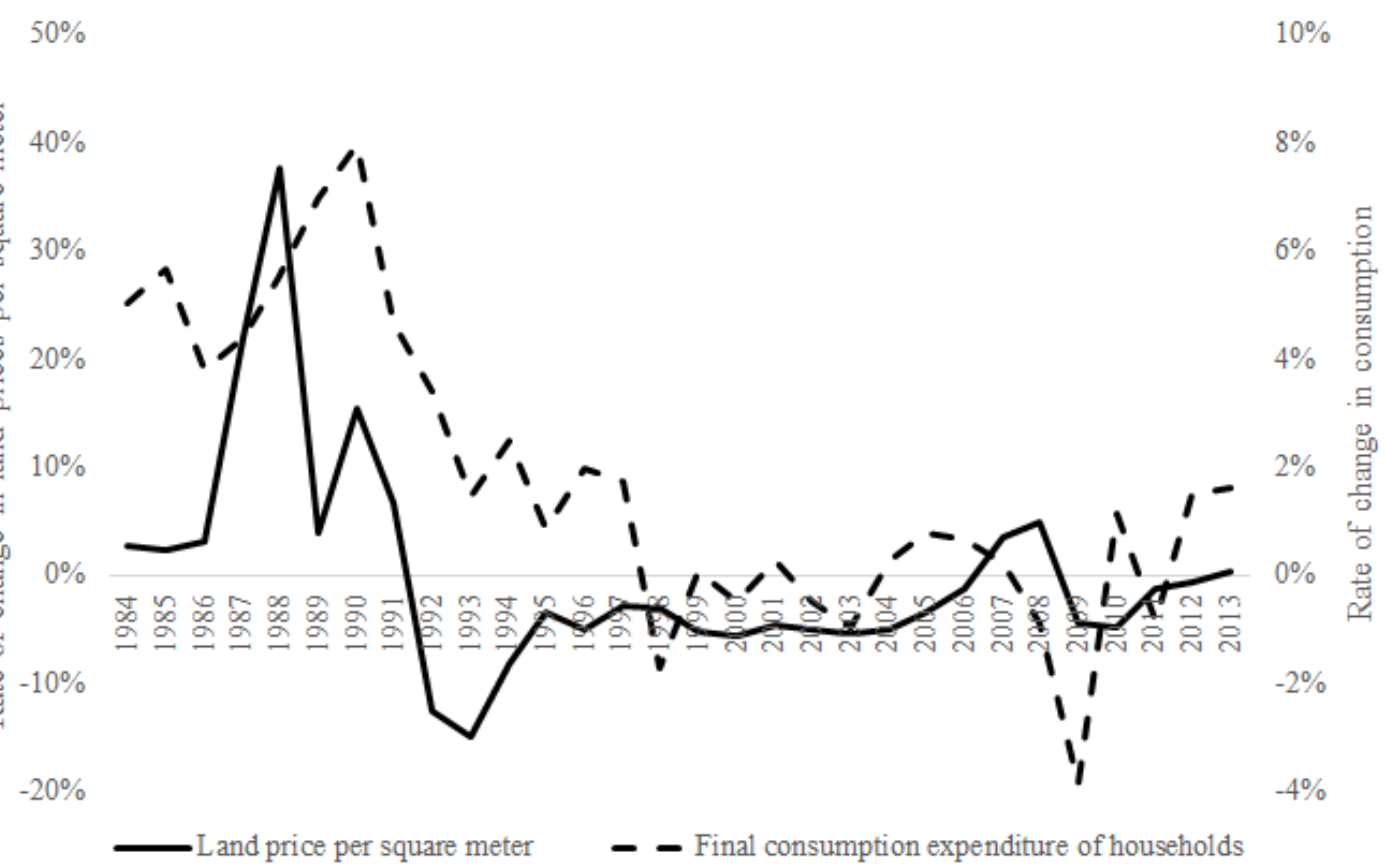


Figure 2

Elasticity of consumption with respect to the land price per square meter
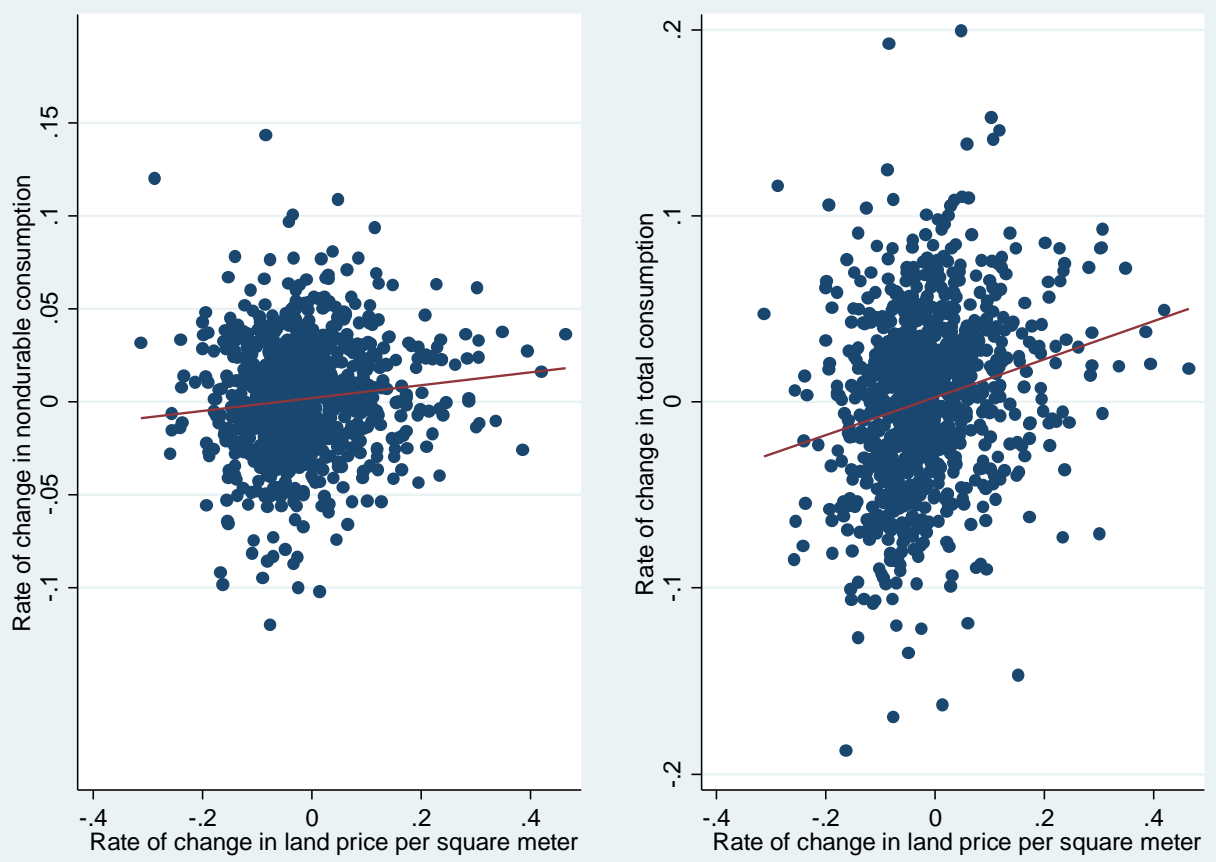
Table 1

Descriptive statistics

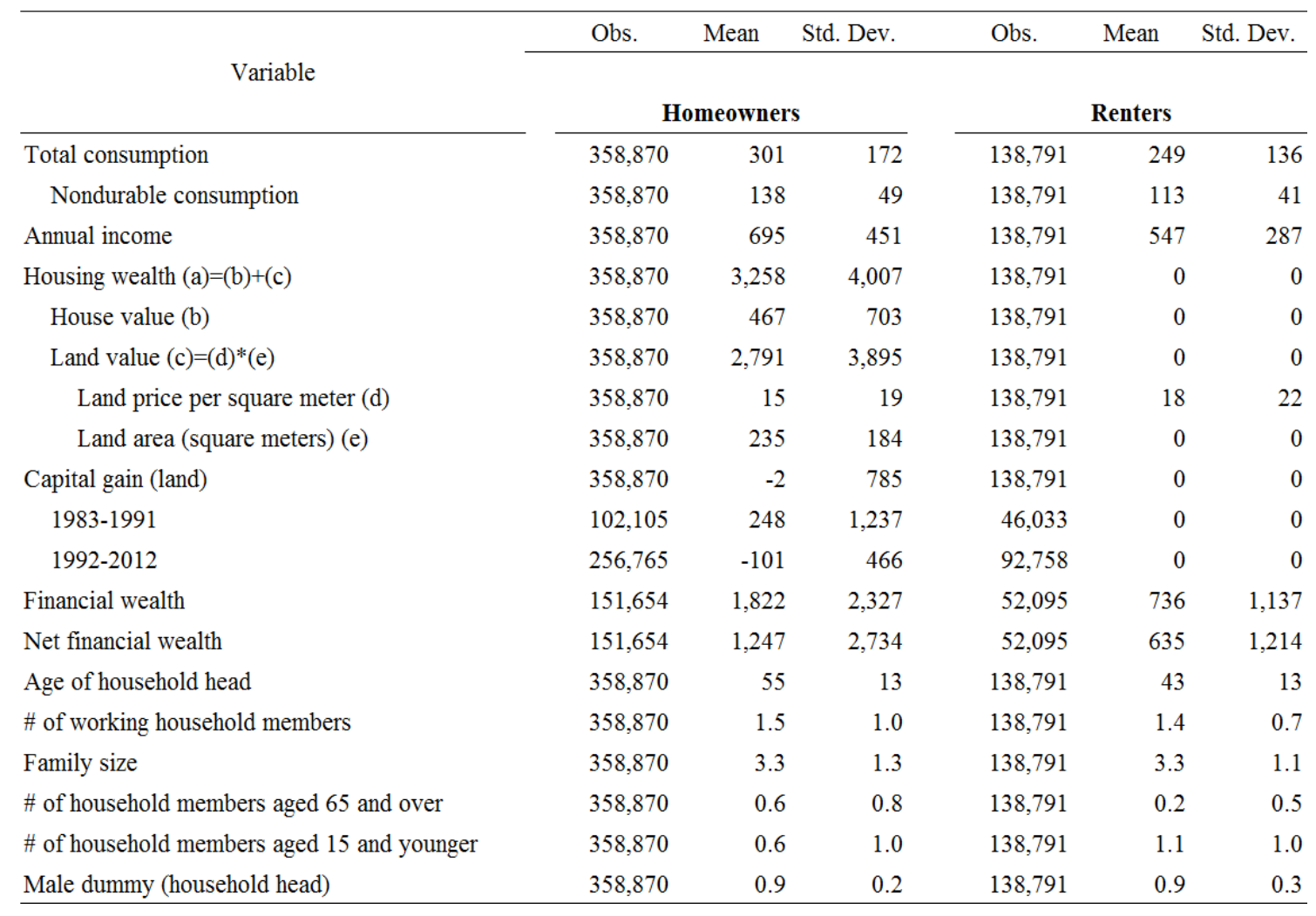

Notes: All monetary variables are in 10,000 yen. Housing-related expenditures are subtracted from total consumption. Annual income is the previous year's pretax annual income. Net financial wealth is calculated by subtracting outstanding debt from financial wealth. The observation period is 1983-2012. As for financial wealth and debt, only a limited number of households were surveyed before 2002. Capital gain is calculated by taking the first difference on the land value based on the assumption that, normally, the land area for each household is constant over time. 
Table 2

Regression results (cross-sectional data)

\begin{tabular}{|c|c|c|c|c|c|c|c|c|}
\hline \multirow{3}{*}{ Dependent variable: } & (1) & (2) & (3) & (4) & (5) & (6) & (7) & (8) \\
\hline & \multicolumn{4}{|c|}{ Nondurable consumption } & \multicolumn{4}{|c|}{ Total consumption } \\
\hline & & & & Aged 65 or older & & & & Aged 65 or older \\
\hline \multirow[t]{2}{*}{ Housing wealth } & $0.00100^{* * *}$ & $0.00120^{* * *}$ & $0.00123^{* * *}$ & $0.00143^{* * *}$ & $0.00328^{* * * *}$ & $0.00351^{* * *}$ & $0.00361^{* * *}$ & $0.00329^{* * *}$ \\
\hline & $(0.0000339)$ & $(0.0000785)$ & $(0.0000888)$ & $(0.0000906)$ & $(0.000128)$ & $(0.000266)$ & $(0.000299)$ & $(0.000320)$ \\
\hline Housing wealth & \multicolumn{4}{|c|}{$-0.000370^{* * *}$} & & \multicolumn{3}{|c|}{$-0.00157^{* * *}$} \\
\hline Young & \multicolumn{4}{|c|}{$(0.000131)$} & & \multicolumn{3}{|c|}{$(0.000483)$} \\
\hline Net financial wealth & No & Yes & Yes & Yes & No & Yes & Yes & Yes \\
\hline \multirow[t]{2}{*}{ MPC out of HW for Young } & \multicolumn{4}{|c|}{$0.00086^{* * 4}$} & & \multicolumn{3}{|c|}{$0.00205^{* * *}$} \\
\hline & \multicolumn{4}{|c|}{$(0.00010)$} & & \multicolumn{3}{|c|}{$(0.00040)$} \\
\hline $\mathrm{N}$ & 497,661 & 203,749 & 203,749 & 54,573 & 497,661 & 203,749 & 203,749 & 54,573 \\
\hline Adj. R-sq & 0.357 & 0.351 & 0.352 & 0.283 & 0.280 & 0.299 & 0.300 & 0.270 \\
\hline
\end{tabular}

Notes: The dependent variable is annualized nondurable or total consumption (excluding housing-related expenditure). All regressions include the age, sex, industry of occupation, and type of work of the household head, the previous year's (pre-tax) income, the prefecture of residence, family size, the number of household members aged 65 and over, the number of household members aged 15 and under, year dummies, cohort dummies, an urban dummy, and first month of the survey dummies. All monetary variables are converted into real terms using prefectural CPIs and are in 10,000 yen. The dummy "Young" takes one if the head of household is aged 40 or below and zero otherwise. Robust standard errors are in parentheses. ${ }^{* *}, * *$ and $*$ indicate statistical significance at the 1 , 5 and 10\% levels respectively. The results of the test that examines whether the MPC out of housing wealth for young households is statistically different from zero are shown at the bottom of the table. 
Table 3

Regression results (pseudo-panel data, log-log specification)

\begin{tabular}{|c|c|c|c|c|c|c|c|c|}
\hline & (1) & (2) & (3) & (4) & (5) & (6) & (7) & (8) \\
\hline Dependent variable: & \multicolumn{2}{|c|}{$\Delta \ln (\mathrm{ND})$} & \multicolumn{2}{|c|}{$\Delta \ln (\mathrm{C})$} & \multicolumn{2}{|c|}{$\Delta \ln (\mathrm{ND})$} & \multicolumn{2}{|c|}{$\Delta \ln (C)$} \\
\hline$\Delta \ln$ (Housing wealth) & $\begin{array}{l}0.0236^{* * *} \\
(0.00865)\end{array}$ & $\begin{array}{l}0.0531^{* * *} \\
(0.0131)\end{array}$ & $\begin{array}{l}0.0411^{* * *} \\
(0.0150)\end{array}$ & $\begin{array}{l}0.105^{* * *} \\
(0.0206)\end{array}$ & & & & \\
\hline $\begin{array}{l}\Delta \ln \text { (Housing wealth) } \\
* \text { Young }\end{array}$ & & $\begin{array}{c}-0.0540^{* * *} \\
(0.0163)\end{array}$ & & $\begin{array}{l}-0.114^{* * *} \\
(0.0259)\end{array}$ & & & & \\
\hline$\Delta \ln$ (Price) & & & & & $\begin{array}{l}0.0217^{*} \\
(0.0112)\end{array}$ & $\begin{array}{l}0.0352^{* \% *} \\
(0.0121)\end{array}$ & $\begin{array}{l}0.0688^{* 4 \%} \\
(0.0184)\end{array}$ & $\begin{array}{l}0.102^{\phi+\phi} \\
(0.0197)\end{array}$ \\
\hline $\begin{array}{l}\Delta \ln \text { (Price) } \\
\text { Young }\end{array}$ & & & & & & 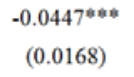 & & 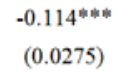 \\
\hline MPC $(\beta \times \mathrm{C} / \mathrm{HW})$ & 0.0013 & & 0.0049 & & 0.0012 & & 0.0082 & \\
\hline $\begin{array}{l}\text { Old } \\
\text { Young }\end{array}$ & & $\begin{array}{l}0.0026 \\
-0.0001\end{array}$ & & $\begin{array}{l}0.0111 \\
-0.0020\end{array}$ & & $\begin{array}{l}0.0017 \\
-0.0009\end{array}$ & & $\begin{array}{l}0.0108 \\
-0.0027\end{array}$ \\
\hline $\begin{array}{l}\text { HW elasticity of consumption } \\
\text { for young }\end{array}$ & & $\begin{array}{c}-0.0009 \\
(0.0108862)\end{array}$ & & $\begin{array}{c}-0.0090 \\
(0.0172394)\end{array}$ & & $\begin{array}{c}-0.0095 \\
(0.0155111)\end{array}$ & & $\begin{array}{c}-0.0125 \\
(0.0249934)\end{array}$ \\
\hline $\mathrm{N}$ & 962 & 962 & 962 & 962 & 962 & 962 & 962 & 962 \\
\hline Adj. R-sq & 0.319 & 0.338 & 0.288 & 0.313 & 0.314 & 0.328 & 0.290 & 0.308 \\
\hline
\end{tabular}

Notes: In all specifications, the real interest rate, the rate of change of the previous year's pretax income, family size, the number of working household members, the number of household members aged 15 or below, and the number of household members aged 65 or above are included. In addition, dummies for two-year intervals are also added to eliminate aggregate effects. The MPCs are calculated by multiplying the estimated elasticity by the consumption-housing wealth ratio. Robust standard errors are in parentheses. $* * *, * *$ and $*$ indicate statistical significance at the 1, 5 and $10 \%$ levels respectively. The results of the test that examines whether the elasticity of consumption with respect to housing wealth for young households is statistically different from zero are shown at the bottom of the table. 
Table 4

Regression results (pseudo-panel data, first-difference specification)

\begin{tabular}{|c|c|c|c|c|c|c|c|c|}
\hline \multirow[b]{2}{*}{ Dependent variable: } & (1) & (2) & (3) & (4) & $(5)$ & (6) & (7) & (8) \\
\hline & \multicolumn{2}{|c|}{$\Delta(\mathrm{ND})$} & \multicolumn{2}{|c|}{$\Delta(\mathrm{C})$} & \multicolumn{2}{|c|}{$\Delta(\mathrm{ND})$} & \multicolumn{2}{|c|}{$\Delta(\mathrm{C})$} \\
\hline$\Delta(\text { Price })^{*} \mathrm{Qbar}$ & $\begin{array}{l}0.000833^{* *} \\
(0.000368)\end{array}$ & $\begin{array}{l}0.000887^{* * *} \\
(0.000376)\end{array}$ & $\begin{array}{c}0.00591^{* * * *} \\
(0.00127)\end{array}$ & $\begin{array}{c}0.00627^{* * * *} \\
(0.00128)\end{array}$ & & & & \\
\hline $\begin{aligned} \Delta(\text { Price }) * & \text { Qbar } \\
& * \text { Young }\end{aligned}$ & & $\begin{array}{c}-0.00112 \\
(0.000731)\end{array}$ & & $\begin{array}{c}-0.00682 * * \\
(0.00265)\end{array}$ & & & & \\
\hline$\Delta$ (Price)* $\mathrm{Q}(-1)$ & & & & & $\begin{array}{l}0.000993 * * \\
(0.000397)\end{array}$ & $\begin{array}{l}0.00101^{* *} \\
(0.000400)\end{array}$ & $\begin{array}{l}0.00681^{* * *} \\
(0.00139)\end{array}$ & $\begin{array}{c}0.00688 * * * \\
(0.00138)\end{array}$ \\
\hline $\begin{array}{r}\Delta(\text { Price })^{*} \mathrm{Q}(-1) \\
* \text { Young }\end{array}$ & & & & & & $\begin{array}{l}-0.00105 \\
(0.00111)\end{array}$ & & $\begin{array}{l}-0.00640 \\
(0.00432)\end{array}$ \\
\hline MPC out of HW for Young & & $\begin{array}{l}-0.0002354 \\
(0.0007526)\end{array}$ & & $\begin{array}{l}-0.0005494 \\
(0.0026957)\end{array}$ & & $\begin{array}{l}-0.0000385 \\
(0.0011605)\end{array}$ & & $\begin{array}{l}0.0004801 \\
(0.0044892)\end{array}$ \\
\hline $\mathrm{N}$ & 968 & 968 & 968 & 968 & 968 & 968 & 968 & 968 \\
\hline Adj. R-sq & 0.311 & 0.321 & 0.297 & 0.309 & 0.312 & 0.322 & 0.301 & 0.310 \\
\hline
\end{tabular}

Notes: In all specifications, the real interest rate, the first difference of the previous year's pretax income, family size, the number of working household members, the number of household members aged 15 or below, and the number of household members aged 65 or above are included. In addition, dummies for two-year intervals are also added to eliminate aggregate effects. Robust standard errors are in parentheses. ${ }^{* * *}, * *$ and $*$ indicate statistical significance at the 1, 5 and 10\% levels respectively. The results of the test that examines whether the MPC out of housing wealth for young households is statistically different from zero are shown at the bottom of the table. 
Table 5

Regression results (cross-sectional data, homeowners only)

\begin{tabular}{|c|c|c|c|c|c|c|c|c|}
\hline \multirow{3}{*}{ Dependent variable: } & (1) & (2) & (3) & (4) & (5) & (6) & (7) & (8) \\
\hline & \multicolumn{4}{|c|}{ Nondurable consumption } & \multicolumn{4}{|c|}{ Total consumption } \\
\hline & & & & Aged 65 or older & & & & Aged 65 or olden \\
\hline \multirow[t]{2}{*}{ Housing wealth } & $0.000824^{* * * *}$ & $0.000953^{* * *}$ & $0.000990^{* * *}$ & $0.00114^{* * *}$ & $0.00276^{* * * *}$ & $0.00266^{* * *}$ & $0.00277^{* * *}$ & $0.00247^{* * *}$ \\
\hline & $(0.0000349)$ & $(0.0000782)$ & $(0.0000854)$ & $(0.0000916)$ & $(0.000136)$ & $(0.000269)$ & $(0.000291)$ & $(0.000328)$ \\
\hline Housing wealth & \multicolumn{4}{|c|}{$-0.000455^{* * *}$} & & \multicolumn{3}{|c|}{$-0.00151^{* * *}$} \\
\hline * Young & \multicolumn{4}{|c|}{$(0.000141)$} & & \multicolumn{3}{|c|}{$(0.000551)$} \\
\hline Net financial wealth & No & Yes & Yes & Yes & No & Yes & Yes & Yes \\
\hline \multirow[t]{2}{*}{ MPC out of HW for Young } & \multicolumn{4}{|c|}{$0.0005341^{* * *}$} & & \multicolumn{3}{|c|}{$0.0012589^{* * *}$} \\
\hline & \multicolumn{4}{|c|}{$(0.0001196)$} & & \multicolumn{3}{|c|}{$(0.0004902)$} \\
\hline $\mathrm{N}$ & 358,870 & 151,654 & 151,654 & 49,264 & 358,870 & 151,654 & 151,654 & 49,264 \\
\hline Adj. R-sq & 0.314 & 0.303 & 0.303 & 0.270 & 0.263 & 0.282 & 0.282 & 0.255 \\
\hline
\end{tabular}

Notes: See notes for Table 2. 
Table 6

Regression results (cross-sectional data, renters only)

\begin{tabular}{|c|c|c|c|c|c|c|c|c|}
\hline \multirow{3}{*}{ Dependent variable: } & (1) & (2) & (3) & (4) & (5) & (6) & (7) & (8) \\
\hline & \multicolumn{4}{|c|}{ Nondurable consumption } & \multicolumn{4}{|c|}{ Total consumption } \\
\hline & & & & Aged 65 or older & & & & Aged 65 or olde! \\
\hline \multirow[t]{2}{*}{ Housing wealth } & $0.000194^{* * *}$ & $0.000214^{* *}$ & $0.000397^{* * *}$ & 0.0000918 & $0.00158^{* * *}$ & $0.00109^{* * *}$ & $0.00156^{* * *}$ & 0.000249 \\
\hline & $(0.0000491)$ & $(0.0000851)$ & $(0.000113)$ & $(0.000266)$ & $(0.000346)$ & $(0.000303)$ & $(0.000395)$ & $(0.000820)$ \\
\hline Housing wealth & \multicolumn{4}{|c|}{$-0.000396^{* * *}$} & & \multicolumn{3}{|c|}{$-0.00103^{* *}$} \\
\hline *'Young & \multicolumn{4}{|c|}{$(0.000134)$} & & \multicolumn{3}{|c|}{$(0.000490)$} \\
\hline Net financial wealth & No & Yes & Yes & Yes & No & Yes & Yes & Yes \\
\hline \multirow[t]{2}{*}{ MPC out of HW for Young } & \multicolumn{4}{|c|}{0.000000958} & & \multicolumn{3}{|c|}{0.0005276} \\
\hline & \multicolumn{4}{|c|}{$(0.0001017)$} & & \multicolumn{3}{|c|}{$(0.0003813)$} \\
\hline $\mathrm{N}$ & 138,122 & 51,875 & 51,875 & 5,276 & 138,122 & 51,875 & 51,875 & 5,276 \\
\hline Adj. R-sq & 0.372 & 0.373 & 0.374 & 0.262 & 0.305 & 0.324 & 0.325 & 0.310 \\
\hline
\end{tabular}

Notes: See notes for Table 2. 
Table 7

Regression results (pseudo-panel data, log-log specification, homeowners only)

\begin{tabular}{|c|c|c|c|c|c|c|c|c|}
\hline & (1) & (2) & (3) & (4) & (5) & (6) & (7) & (8) \\
\hline Dependent variable: & \multicolumn{2}{|c|}{$\Delta \ln (\mathrm{ND})$} & \multicolumn{2}{|c|}{$\Delta \ln (\mathrm{C})$} & \multicolumn{2}{|c|}{$\Delta \ln (\mathrm{ND})$} & \multicolumn{2}{|c|}{$\Delta \ln (\mathrm{C})$} \\
\hline$\Delta \ln$ (Housing wealth) & $0.0361^{* *}$ & $0.0390^{* *}$ & $0.0794^{* * *} *$ & $0.104^{* * *}$ & & & & \\
\hline & $(0.0140)$ & $(0.0151)$ & $(0.0225)$ & $(0.0237)$ & & & & \\
\hline$\Delta \ln$ (Housing wealth) & & -0.0134 & & $-0.119 * *$ & & & & \\
\hline * Young & & $(0.0297)$ & & $(0.0479)$ & & & & \\
\hline$\Delta \ln$ (Price) & & & & & $0.0261^{*} *$ & $0.0338 * * *$ & $0.0800^{* * * *}$ & $0.108^{* * *}$ \\
\hline$\Delta \ln$ (Price) & & & & & & -0.0298 & & $-0.111^{*} * *$ \\
\hline * Young & & & & & & $(0.0219)$ & & $(0.0362)$ \\
\hline \multicolumn{9}{|l|}{$\mathrm{MPC}(\beta \times \mathrm{C} / \mathrm{HW})$} \\
\hline Housing wealth & 0.0015 & & 0.0073 & & 0.0011 & & 0.0074 & \\
\hline Old & & 0.0017 & & 0.0095 & & 0.0014 & & 0.0099 \\
\hline Young & & 0.0011 & & -0.0014 & & 0.0002 & & -0.0003 \\
\hline Elasticity out of HW for Young & & 0.0256 & & -0.0142 & & 0.0040 & & -0.0030 \\
\hline & & $(0.0273919)$ & & $(0.0447575)$ & & $(0.0206239)$ & & $(0.0345071)$ \\
\hline $\mathrm{N}$ & 885 & 885 & 885 & 885 & 885 & 885 & 885 & 885 \\
\hline Adj. R-sq & 0.257 & 0.262 & 0.246 & 0.253 & 0.253 & 0.259 & 0.248 & 0.256 \\
\hline
\end{tabular}

Notes: See notes for Table 3. 


\section{Table 8}

Regression results (pseudo-panel data, first difference specification, homeowners only)

\begin{tabular}{|c|c|c|c|c|c|c|c|c|}
\hline & (1) & (2) & (3) & (4) & (5) & (6) & (7) & (8) \\
\hline Dependent variable: & \multicolumn{2}{|c|}{$\Delta(\mathrm{ND})$} & \multicolumn{2}{|c|}{$\Delta(\mathrm{C})$} & \multicolumn{2}{|c|}{$\Delta(\mathrm{ND})$} & \multicolumn{2}{|c|}{$\Delta(\mathrm{C})$} \\
\hline$\Delta(\text { Price })^{*}$ Qbar & $\begin{array}{l}0.000573^{*} \\
(0.000323)\end{array}$ & $\begin{array}{l}0.000712^{* *} \\
(0.000339)\end{array}$ & $\begin{array}{l}0.00518^{* * *} \\
(0.00118)\end{array}$ & $\begin{array}{c}0.00649^{* * * *} \\
(0.00121)\end{array}$ & & & & \\
\hline $\begin{aligned} & \Delta(\text { Price }) * \text { Qbar } \\
& * \text { Young }\end{aligned}$ & & $\begin{array}{l}-0.000729 \\
(0.000704)\end{array}$ & & $\begin{array}{c}-0.00690^{* * *} \\
(0.00253)\end{array}$ & & & & \\
\hline$\Delta($ Price $) * \mathrm{Q}(-1)$ & & & & & $\begin{array}{l}0.000614^{*} \\
(0.000335)\end{array}$ & $\begin{array}{l}0.000746^{* * *} \\
(0.000350)\end{array}$ & $\begin{array}{c}0.00538^{* * * *} \\
(0.00123)\end{array}$ & $\begin{array}{c}0.00667^{* * *} \\
(0.00127)\end{array}$ \\
\hline $\begin{array}{r}\Delta(\text { Price }) * \mathrm{Q}(-1) \\
* \text { Young }\end{array}$ & & & & & & $\begin{array}{l}-0.000732 \\
(0.000749)\end{array}$ & & $\begin{array}{c}-0.00715^{* * *} * \\
(0.00265)\end{array}$ \\
\hline MPC out of HW for Young & & $\begin{array}{l}-0.0000174 \\
(0.0006796)\end{array}$ & & $\begin{array}{l}-0.0004127 \\
(0.0024399)\end{array}$ & & $\begin{array}{c}0.0000138 \\
(0.0007249)\end{array}$ & & $\begin{array}{l}-0.0004729 \\
(0.0025473)\end{array}$ \\
\hline $\mathrm{N}$ & 889 & 889 & 889 & 889 & 889 & 889 & 889 & 889 \\
\hline Adj. R-sq & 0.271 & 0.272 & 0.253 & 0.260 & 0.272 & 0.272 & 0.254 & 0.260 \\
\hline
\end{tabular}

Notes: See notes for Table 4. 
Table 9

Contribution of changes in land prices to household consumption during 1986-1994

\begin{tabular}{|c|c|c|c|c|}
\hline \multirow{3}{*}{ Period } & \multirow{3}{*}{$\begin{array}{l}\text { Rate of change in land prices } \\
\text { (a) }\end{array}$} & \multicolumn{2}{|c|}{ Rate of change in consumption } & \multirow{3}{*}{$\begin{array}{c}\begin{array}{c}\text { Explained } \\
\text { (share) }\end{array} \\
(\mathrm{d})=100^{*}((\mathrm{~b}) /(\mathrm{c}))\end{array}$} \\
\hline & & Explained & Actual & \\
\hline & & $(b)=(a) * 0.0688$ & (c) & \\
\hline 1986-1991 & $154 \%$ & $10.6 \%$ & $33.8 \%$ & $31 \%$ \\
\hline 1991-1994 & $-41 \%$ & $-2.8 \%$ & $8.9 \%$ & n.a. \\
\hline
\end{tabular}

Note: The elasticity of total consumption with respect to land prices per square meter is taken from specification (7) in Table 3. 